\title{
PERUBAHAN TANDA VITAL PADA PASIEN HEMODIALISIS SEBELUM, SAAT DAN SETELAH HEMODIALISIS DI RSUD MARDI WALUYO KOTA BLITAR
}

\author{
Tri Cahyo Sepdianto ${ }^{1}$, Nanda Putri Septiana ${ }^{2}$, Suprajitno ${ }^{3}$ \\ 1, 3, Dosen Poltekkes Kemenkes Malang \\ 2, Mahasiswa Keperawatan Poltekkes Kemenkes Malang \\ *Email:cahyo_sepdianto@yahoo.com
}

\begin{abstract}
Abstrak
Hemodialisis adalah proses sebagai pergerakan larutan dan air dari darah pasien melewati membrane semipermiabel (dialyzer) ke dalam diasilat. Tujuan penelitian ini adalah mendeskripsikan perubahan tanda vital pada pasien hemodialisis sebelum, saat dan setelah hemodialisis di RSUD Mardi Waluyo Kota Blitar. Metode penelitian yang digunakan ini adalah penelitian deskriptif. Penelitian ini melibatkan 30 responden. Pengumpulan data menggunakan kuesioner dan lembar pengukuran. Hasil penelitian menunjukkan tekanan darah sistolik mengalami penurunan sebesar 5,67 mmHg. Kemudian perubahan tekanan darah diastolik mengalami penurunan sebesar 2,33 $\mathrm{mmHg}$. Perubahan frekuensi nadi mengalami peningkatan sebesar 4,43 x/menit. Frekuensi pernafasan mengalami penurunan sebesar $0,13 \mathrm{x} /$ menit. Perubahan suhu mengalami peningkatan sebesar $0,03^{\circ} \mathrm{C}$. Rekomendasi pada pasien hemodialisis agar memantau perubahan tanda vital agar tidak terjadi komplikasi dan gangguan hemodinamik.
\end{abstract}

Kata kunci : Hemodialisis, Perubahan Tanda Vital

\begin{abstract}
Changes in Vital Signs Hemodialysis Patients Before, During and After Hemodialysis in Mardi Waluyo Hospital Blitar City: Hemodialysis is the process of moving the solution and water from the patient's blood through the semipermile (dialyzer) membrane into the extract. The purpose of this study to describe change vital signs in hemodialysis patients before, during and after hemodialysis in Mardi Waluyo Hospital Blitar City. The methodology of this research is descriptif research design. The research sample consisted of 30 respondents. Data collection uses quesionare and measurement sheets. The results showed a decrease in systolic blood pressure of $5.67 \mathrm{mmHg}$. Then change in diastolic blood pressure decreased by $2.33 \mathrm{mmHg}$. The change in pulse frequency increased by $4.43 x /$ minute. The change in respiratory frequency decreased by $0.13 x /$ minute. The temperature change has increased by $0.03{ }^{\circ} \mathrm{C}$. Recommendations for hemodialysis patients to monitor changes in vital signs to avoid complications and hemodynamic disorders.
\end{abstract}

Keywords: Hemodialysis, Changes in Vital Signs 


\section{Pendahuluan}

Gagal ginjal adalah kondisi dimana saat fungsi ginjal mengalami suatu perubahan secara bertahap. Tahap awal gagal ginjal tidak merasakan sakit tetapi sering terjadi uremia (Rosdahl \& Kowalski, 2014). Tanda dan gejala gagal ginjal ditandai dengan penurunan berat badan, terdapat perdarahan pada urine, muntah dan diare, pembengkakan tungkai, sesak nafas dan sulit berkemih (Nair \& Peate, 2018).

Penatalaksanaanan dari gagal ginjal kronis adalah hemodialisis dan tranpatasi ginjal. Terapi yang paling umum bagi pasien dengan gagal ginjal kronis yaitu hemodialisis. Hemodialisis adalah proses sebagai pergerakan larutan dan air dari darah pasien melewati membrane semipermiabel (dialyzer) ke dalam dialisat (Nuari, 2017). Hasil studi pendahuluan dilakukan peneliti tercatat pada tahun 2017 di RSUD Mardi Waluyo didapatkan 181 orang menjalani hemodialysis dengan 76,7\% mengalami CKD. Pada tahun 2018 di RSUD Mardi Waluyo pasien hemodialis meningkat menjadi 205 orang dan 90,7\% mengalami CKD.

Hemodialisis memang aman tetapi mempunyai risiko komplikasi. Komplikasi hemodialisis antara lain perubahan tanda vital, hipotensi dan hipertensi, emboli udara, nyeri dada, gangguan keseimbangan dialysis, dan pruritus. Komplikasi ini bisa menimbulkan masalah baru yang lebih komplkes berupa ketidaknyamanan, meningkatkan stress, dan mempengaruhi kualitas hidup memperburuk pasien dan bahkan menimbulkan kematian.

Komplikasi selama proses hemodialisis perlu diantisipasi dan dicegah. Pemantauan secara ketat tanda vital sebelum, saat dan sesudah hemodialisis merupakan salah satu upaya untuk mencegah komplikasi hemodialysis. Rumusan Masalah dalam penelitian ini bagaimanakah Perubahan Tanda Vital Pada Pasien Hemodialisis Sebelum, Saat Dan Setelah Hemodialisis Di RSUD Mardi Waluyo Kota Blitar. Penelitian ini bertujuan mendeskripsikan Perubahan Tanda Vital Pada Pasien Hemodialisis Sebelum, Saat Dan Setelah Hemodialisis Di RSUD Mardi Waluyo Kota Blitar.

\section{Metode}

Rancangan penelitian yang digunakan pada penelitian ini adalah rancangan penelitian deskriptif. Penelitian ini dilakukan di RSUD Mardi Waluyo Kota Blitar pada Bulan April 2019. Populasi dalam penelitian ini pasien GGK yang menjalani Hemodialisis di RSUD Mardi Waluyo Kota Blitar sebanyak 260 orang. Sampel penelitian sebanyak 30 orang dan diambil dengan teknik purposive sampling. Kriteria inklusi responden yaitu: (1) Pasien GGK. (2) Pasien GGK yang menjalani Hemodialisis di 
RSUD Mardi Waluyo. Variabel dalam penelitian ini adalah perubahan tanda vital pada pasien hemodialisis sebelum, saat dan setelah hemodialisis di RSUD Mardi Wluyo kota Blitar. Instrumen penelitian menggunakan kuesioner dan lembar observasi pengukuran untuk mengetahui
Perubahan Tanda Vital Pada Pasien Hemodialisis yang meliputi tekanan darah sistolik dan diastolik, frekuensi nadi, frekuensi pernafasan dan suhu tubuh. Analisis penelitian menggunakan analisis deskriftif.

\section{Hasil}

Tabel 1. Perubahan Tanda Vital Pasien Hemodialisis di RSUD Mardi Waluyo April 2019

\begin{tabular}{|c|c|c|c|}
\hline Tanda vital & Sebelum & Sesaat & Setelah \\
\hline \multicolumn{4}{|l|}{ Tekanan Sistolik } \\
\hline a.Rata-rata & 128.0 & 122.3 & 122.3 \\
\hline b.Standart Deviasi & 12.4 & 12.7 & 15.6 \\
\hline c. Max & 150 & 140 & 150 \\
\hline d. Min & 100 & 90 & 90 \\
\hline \multicolumn{4}{|l|}{ Tekanan Diastolik } \\
\hline a.Rata- rata & 85.33 & 83.33 & 83.00 \\
\hline b.Standart Deviasi & 8.60 & 11.84 & 10.87 \\
\hline c Max & 100 & 110 & 100 \\
\hline d. Min & 70 & 60 & 70 \\
\hline \multicolumn{4}{|l|}{ Nadi } \\
\hline a.Rata- rata & 75.33 & 77.33 & 79.76 \\
\hline b.Standart Deviasi & 8.64 & 6.72 & 8.66 \\
\hline c. Max & 92 & 88 & 96 \\
\hline d. Min & 60 & 66 & 66 \\
\hline \multicolumn{4}{|c|}{ Frekuensi Pernafasan } \\
\hline a.Rata- rata & 20.56 & 20.50 & 20.43 \\
\hline b.Standart Deviasi & 1.10 & 1.25 & 0.93 \\
\hline c. Max & 25 & 24 & 22 \\
\hline d. Min & 20 & 18 & 18 \\
\hline \multicolumn{4}{|l|}{ Suhu } \\
\hline a.Rata- rata & 36.49 & 36.50 & 36.43 \\
\hline b.Standart Deviasi & 0.31 & 0.27 & 0.16 \\
\hline c. $\operatorname{Max}$ & 37 & 37 & 36,9 \\
\hline d. Min & 36 & 36 & 36 \\
\hline
\end{tabular}

Tabel 2. Perubahan Tekanan Sistolik Pasien Hemodialisis di RSUD Mardi Waluyo April 2019

\begin{tabular}{|c|c|c|c|c|c|c|c|c|}
\hline \multirow{3}{*}{$\begin{array}{l}\text { Waktu } \\
\text { pemeriksaan }\end{array}$} & \multicolumn{8}{|c|}{ Tekanan Sistolik } \\
\hline & \multicolumn{2}{|c|}{ Rendah } & \multicolumn{2}{|c|}{ Normal } & \multicolumn{2}{|c|}{ Tinggi } & \multicolumn{2}{|c|}{ Jumlah } \\
\hline & $\mathrm{F}$ & $\%$ & $\mathrm{~F}$ & $\%$ & $\mathrm{~F}$ & $\%$ & $\mathrm{~F}$ & $\%$ \\
\hline Sebelum & 2 & 11 & 19 & 36 & 9 & 45 & 30 & 100 \\
\hline Saat & 6 & 33 & 19 & 37 & 5 & 25 & 30 & 100 \\
\hline Setelah & 10 & 56 & 14 & 27 & 6 & 30 & 30 & 100 \\
\hline
\end{tabular}


Pasien yang menjalani hemodialisis memiliki tekanan darah sitolik dalam rentang normal ketika sebelum sebesar 36\% (19 pasien), saat sebesar 37\% (19 pasien), dan setelah sebesar $14 \%$ (14 pasien). rentang rendah ketika sebelum sebesar 11\%(2 pasien), saat sebesar $33 \%$ (6 pasien), dan setelah sebesar 56\% (10 pasien). rentang tinggi ketika sebelum sebesar 45\% (9 pasien), saat sebesar 5\% (25 pasien), dan setelah sebesar $6 \%$ (30 pasien).

Tabel 3 Perubahan Tekanan Diastolik Pasien Selama Sebelum,Saat, dan Setelah Hemodialisis di RSUD Mardi Waluyo April 2019

\begin{tabular}{lcccccccccc}
\hline Waktu pemeriksaan & \multicolumn{8}{c}{ Tekanan diastolic } \\
\cline { 2 - 10 } & \multicolumn{2}{c}{ Rendah } & \multicolumn{2}{c}{ Normal } & \multicolumn{2}{c}{ Tinggi } & \multicolumn{2}{c}{ Jumlah } \\
Sebelum & 2 & 11 & 15 & 47 & 13 & 34 & 30 & 100 \\
Saat & 8 & 42 & 9 & 28 & 13 & 33 & 30 & 100 \\
Setelah & 9 & 47 & 8 & 25 & 13 & 33 & 30 & 100 \\
\hline
\end{tabular}

Pasien yang menjalani hemodialisis memiliki tekanan diastolic dalam rentang normal ketika sebelum sebesar $47 \% \quad(15$ pasien), saat sebesar $28 \%$ ( 9 pasien), dan setelah sebesar $25 \%$ (8 pasien). rentang rendah ketika sebelum sebesar $11 \% \quad(2$ pasien), saat sebesar $42 \%$ (8 pasien), dan setelah sebesar $47 \%$ (9 pasien). rentang tinggi ketika sebelum sebesar 34\% (13 pasien), saat sebesar 33\% (13 pasien), dan setelah sebesar $33 \%$ (13 pasien).

Tabel 4. Perubahan Frekuensi Nadi Pasien Hemodialisis di RSUD Mardi Waluyo April 2019

\begin{tabular}{|c|c|c|c|c|c|c|c|c|}
\hline \multirow{3}{*}{$\begin{array}{c}\text { Waktu } \\
\text { pemeriksaan }\end{array}$} & \multicolumn{8}{|c|}{ Frekuensi Nadi } \\
\hline & \multicolumn{2}{|c|}{ Rendah } & \multicolumn{2}{|c|}{ Normal } & \multicolumn{2}{|c|}{ Tinggi } & \multicolumn{2}{|c|}{ Jumlah } \\
\hline & $\mathrm{F}$ & $\%$ & $\mathrm{~F}$ & $\%$ & $\mathrm{~F}$ & $\%$ & $\mathrm{~F}$ & $\%$ \\
\hline Sebelum & 0 & 0 & 30 & 100 & 0 & 0 & 30 & 100 \\
\hline Saat & 0 & 0 & 30 & 100 & 0 & 0 & 30 & 100 \\
\hline Setelah & 0 & 0 & 30 & 100 & 0 & 0 & 30 & 100 \\
\hline
\end{tabular}

Pasien yang menjalani hemodialisis ada perubahan sebelum,saat dan setelah tetapi perubahan masih dalam rentang normal. Frekuensi nadi dalam rentang normal ketika sebelum sebesar $100 \%$ (30 pasien), saat sebesar $100 \%$ (30 pasien), dan setelah sebesar 100\% (30 pasien). 
Tabel 5. Perubahan Frekuensi Pernafasan Pasien Hemodialisis di RSUD Mardi Waluyo April 2019

\begin{tabular}{llllllllll}
\hline Waktu & \multicolumn{8}{c}{ Frekuensi Pernafasan } \\
\cline { 2 - 10 } & \multicolumn{2}{c}{ Rendah } & \multicolumn{2}{c}{ Normal } & \multicolumn{2}{c}{ Tinggi } & \multicolumn{2}{c}{ Jumlah } \\
Sebelum & 0 & 0 & 20 & 35 & 10 & 30 & 30 & 100 \\
Saat & 0 & 0 & 16 & 28 & 14 & 43 & 30 & 100 \\
Setelah & 0 & 0 & 21 & 37 & 9 & 27 & 30 & 100 \\
\hline
\end{tabular}

Pasien yang menjalani hemodialisis ada perubahan sebelum,saat dan setelah tetapi perubahan masih dalam rentang normal dan rentang tinggi. rentang normal ketika sebelum sebesar $35 \%$ (20 pasien), saat sebesar $28 \%$
(16 pasien), dan setelah sebesar $37 \%(21$ pasien). rentang tinggi ketika sebelum sebesar $30 \%$ (10 pasien), saat sebesar 43\% (14 pasien), dan setelah sebesar $27 \%$ (9 pasien).

Tabel 6. Perubahan Suhu Pasien Hemodialisis di RSUD Mardi Waluyo April 2019

\begin{tabular}{|c|c|c|c|c|c|c|c|c|}
\hline \multirow[t]{3}{*}{ Waktu pemeriksaan } & \multicolumn{8}{|c|}{ Suhu } \\
\hline & \multicolumn{2}{|c|}{ Rendah } & \multicolumn{2}{|c|}{ Normal } & \multicolumn{2}{|c|}{ Tinggi } & \multicolumn{2}{|c|}{ Jumlah } \\
\hline & $\mathrm{F}$ & $\%$ & $\mathrm{~F}$ & $\%$ & $\mathrm{~F}$ & $\%$ & F & $\%$ \\
\hline Sebelum & 4 & 57 & 26 & 31 & 0 & 0 & 30 & 100 \\
\hline Saat & 2 & 29 & 28 & 34 & 0 & 0 & 30 & 100 \\
\hline Setelah & 1 & 14 & 29 & 35 & 0 & 0 & 30 & 100 \\
\hline
\end{tabular}

Pasien yang menjalani hemodialisa ada perubahan sebelum,saat dan setelah tetapi perubahan masih dalam rentang normal dan rentang rendah. rentang normal ketika sebelum sebesar $31 \%$ (26 pasien), saat sebesar 34\% (28 pasien), dan setelah sebesar 35\% (29 pasien). rentang rendah ketika sebelum sebesar 57\% (4 pasien), saat sebesar $29 \%$ ( 2 pasien), dan setelah sebesar $14 \%$ (1 pasien).

\section{Pembahasan}

1. Perubahan Tanda Vital Pasien

Berdasarkan hasil dari penelitian Hemodialisis Selama Sebelum, Saat, dan Setelah Hemodialisis dengan menggunakan lembar pengukuran, didapatkan bahwa perubahan Tanda vital 
Rata-rata perubahan Tanda vital pada pasien hemodialisis tekanan darah sistolik sebelum ke setelah tekanan darah sistolik mengalami penurunan sebesar 5,67 $\mathrm{mmHg}$. Kemudian rata-rata perubahan tekanan diastoliksebelum ke setelah mengalami penurunan sebesar 2,33 mmHg. Rata-rata perubahan frekuensi nadi sebelum ke setelah nadi mengalami peningkatan sebesar 4,43 x/menit. Rata rata perubahan pada frekuensi pernafasan sebelum ke setelah mengalami penurunan sebesar $0,13 x /$ menit. rata-rata perubahan pada suhu sebelum ke setelah suhu mengalami peningkatan sebesar 0,03 derajat celcius.

Menurut Nuari (2017), perubahan tekanan darah pada pasien hemodialisis karena Kadar kalium darah yang tinggi dan kadar natrium darah yang rendah terhadap penurunan tekanan darah. Menurut Inrig, k (2009) perubahan frekuensi nadi dengan hemodialisis menunjukkan kalsium serum lebih tinggi. $\mathrm{CA}+$ menjadikan tolak ukur adanya perubahan frekuensi nadi jika serum lebih tinggi maka frekuensi nadinya juga tinggi juga sebaliknya. Palamidas F. A (2014) Pola pernapasan Frekuensi Pernafasan yang tinggi sebelum dan sesudah hemodialisis. meningkat sebelum hemodialisis dan menurun secara signifikan setelah hemodialisis pada semua pasien. Suhu kulit menurun secara signifikan selama isotermik dan pendinginan, tetapi tidak selama termoneutral. Kadar BP sistolik nadir (SBP) lebih rendah selama isotermik dan termoneutral dibandingkan dengan pendinginan. CBV cenderung lebih tinggi selama pendinginan dibandingkan dengan isothermic dan termoneutral Sande (2009).

Sesuai dengan teori diatas pasien mengalami perubahan tanda vital yang mengalami penurunan yakni tekanan darah sistolik mengalami penurunan, tekanan darah diastolic mengalami penurunan, frekuensi nadi mengalami peningkatan, frekuensi pernafasan mengalami penurunan dan suhu mengalami peningkatan. Hal ini menunjukkan bahwa benar adanya perubahan tanda vital pada pasien hemodialisis. Menjadi sangat penting memonitor Tanda vital pada pasien hemodialisis guna mencegah gangguan hemodinamik ataupun komplikasi lainnya.

\section{Perubahan Tanda vital pada pasien} Hemodialisis Sebelum, Saat, Setelah. Hemodilisis di RSUD Mardi Waluyo

Berdasarkan hasil dari penelitian dengan menggunakan lembar pengukuran, didapatkan bahwa rata-rata Tanda vital dari sebelum, saat dan setelah hemodialisis yang mengalami perubahan Tanda vital pada pasien hemodialisis.ada perubahan tekanan darah sistolik pada sebelum dan setelah yaitu sebelum sebesar 36\% (19 pasien) dan setelah sebesar 14\% (14 pasien). Hal ini menunjukan bahwa adanya penurunan jumlah pasien tekananan darah sistol dalam rentang normal. 
Ada perubahan tekanan darah diastolic pada sebelum dan setelah yaitu sebelum sebesar 47\% (15 pasien) dan dan setelah sebesar $25 \%$ (8 pasien).Hal ini menunjukan bahwa adanya penurunan jumlah pasien tekananan darah diastol dalam rentang normal. Perubahan frekuensi nadi sebelum sebesar 34\% (30 pasien) dan setelah sebesar 33\% (30 pasien). Hal ini menunjukkan ada perubahan sebelum dan setelah tetapi perubahan masih dalam rentang normal. Perubahan Frekuensi Pernafasan sebelum dan setelah sebelum sebesar 35\% (20 pasien) dan setelah sebesar $37 \%$ (21 pasien). Hal ini menunjukkan ada perubahan pada frekuensi pernafasan tetapi dalam batas normal. Dan terakhir perubahan pada suhu sebelum sebesar $31 \%$ (26 pasien) dan setelah sebesar 35\% (29 pasien).

Menurut Nuari (2017), perubahan tekanan darah pada pasien hemodialisis karena Kadar kalium darah yang tinggi dan kadar natrium darah yang rendah terhadap penurunan tekanan darah. Inrig, k (2009) rata rata pra dan pasca dialysis perubahan frekuensi nadi (PP) selama dialysis. Jadi perubahan frekuensi nadi dengan hemodialisis menunjukkan kalsium serum lebih tinggi.

Sesuai dengan teori di atas, Tanda vital pada pasien hemodialisis akan mengalami perubahan sebelum, saat dan setelah proses hemodialisis. Oleh karena itu pemantauan Tanda vital sangat diperlukan karena mencegah terjadinya komplikasi berkelanjutan.

\section{Kesimpulan}

Perubahan tanda tanda vital pada pasien hemodialisis sebelum, saat dan sesudah. Tanda vital yang mengalami penurunan adalah tekanan sistolik sebesar 5,67 $\mathrm{mmHg}$, tekanan diastolic sebesar 2,33 $\mathrm{mmHg}$ dan frekuensi pernafasan sebesar $0,13 \mathrm{x} /$ menit. Tanda vital yang mengalami peningkatan frekuensi nadi sebanyak 4,43 x/menit dan suhu sebanyak $0,03{ }^{\circ} \mathrm{C}$. Bagi pasien Gagal ginjal kronik diharapkan lebih termotivasi dan meningkatkan keinginan untuk selalu mengontol tanda dan gejala komplikasi hemodialisis. Sedangkan bagi peneliti lain hendaknya hasil meningkatkan mutu pelayanan di bidang edukasi dan penyuluhan utamanya, dapat juga dijadikan sebagai acuan untuk perencanaan program selanjutnya dan dapat memberikan sumbangan pemikiran baru tentang Perubahan Tanda Vital pada Pasien Hemodialisis Sebelum, Saat dan Setelah hemodialisis. 
Tri Cahyo Sepdianto, Nanda Putri Septiana, Suprajitno. Perubahan Tanda Vital Pada Pasien Hemodialisis Sebelum, Saat Dan Setelah Hemodialisis di RSUD Mardi Waluyo Kota Blitar

\section{Referensi}

Frank M, dkk. (2009). Control of Core Temperature and Blood Pressure Stability during Hemodialysis (https://www.ncbi.nlm.nih.gov/pubmed /1884294, diakses 24 Juni 2019)

Hidayat, A. A. (2008). Riset Keperawatan dan Teknik Penulisan Ilmiah. Jakarta: Salemba Medika.

Inrig,K, dkk. (2009). Decrease pulse pressure during hemodialysis is Asociated with improved six mounth outcome. (https://www.ncbi.nlm.nih.gov/pmc/ articles/PMC2872933/, diakses 27 November 2018).

Nair\& Peate. (2015). Pathophysiologi for Nurses at a glance. English: Willey Blackwell

Nurari AN, Widyawati D. (2017). Gangguan pada Sistem Perkemihan \& Penatalaksanaan Keperawatan. Yogyakarta: CV Budi Utama

Palamidas F.A, dkk. (2014). Impact of Hemodialysis on Dyspnea and Lung Function in End Stage Kidney Disease Patients (https://www.ncbi.nlm.nih.gov/pmc/arti cles/PMC4034396/ Diakses tanggal 24 November 2018)

Rosdahl, C, dkk. (2014). Volume 5 Buku Ajar Keperawatan Dasar edisi 10. Jakarta: ECG

\section{7}

Setiadi. (2013). Konsep Dan Praktik Penulisan Riset Keperawatan Edisi 2. Yogyayakarta: Graha Ilmu Suprajitno, Sri M. (2018). Studi kasus sebagai riset. Yogyakarta : Andi Surya. 01. 